\title{
Kajian Komparatif Parameter Ekonomi (Harga Susu dan Pakan) Terhadap Efisiensi Penggunaan Teknologi Pakan Pada Usaha Sapi Perah
}

\author{
B. S. Hertanto \\ Program Studi Peternakan, Fakultas Pertanian, Universitas Sebelas Maret \\ Jl. Ir. Sutami 36 A, Kentingan, Surakarta \\ Email: hertsby@yahoo.co.id
}

\begin{abstract}
ABSTRAK
Penelitian ini bertujuan untuk mengkaji dampak penggunaan teknologi pakan sapi perah terhadap perubahan parameter harga susu dan pakan, serta efisiensi penggunaan teknologi pakan. Penelitian dilakukan dengan menggunakan sapi perah Peranakan Friesian Holstein (PFH) laktasi awal (1-3 bulan) sebanyak 15 ekor yang dikelompokkan ke dalam 3 kelompok percobaan berdasarkan penggunaan teknologi pakan. Parameter produksi yang diukur yaitu produksi susu dan kualitas susu selama 42 hari. Parameter ekonomi yaitu harga susu dan harga pakan. Produksi susu tertinggi ditunjukkan dengan menggunakan teknologi pakan III sebesar 11,845 1/ekor/hari. Kualitas susu terbaik secara keseluruhan ditunjukkan oleh penggunaan teknologi pakan II yaitu lemak 3,960\%, Solid Non Fat (SNF) 8,312\%, Total Solid (TS) 12,272\%, Berat Jenis (BJ) 1,029. Hasil penelitian menunjukkan bahwa biaya pakan termurah diperoleh dengan menggunakan teknologi pakan III sebesar Rp. 1.143,80 /liter susu. Hasil perhitungan Income Over Feed Cost (IOFC) menunjukkan penggunaan teknologi pakan III lebih efisien dibandingkan teknologi pakan yang lain yaitu sebesar Rp. 24.664,55/ekor/hari dengan harga susu Rp. 4.207,55 per liter.
\end{abstract}

Kata kunci: teknologi pakan, produksi susu, kualitas susu, harga susu, harga pakan

\section{The Comparative Study of Economic Parameters (Milk and Feed Price) on the Efficiency of Feed Technology in Dairy Farm}

\begin{abstract}
The objective of the study was to evaluate the impact of feed technology on changing of milk and feed price, and also its impact on efficiency of feed technology in dairy farm. In this study, fifteen lactating dairy cows were divided into 3 groups based on the feed technology. Production parameters measured were milk production and quality for 42 days, while economic parameters were milk and feed price. The highest milk production was produced by feed technology III which was Rp. 11,845 l/herd/day. The highest milk quality was resulted in by feed technology II with quality standard of fat 3.960\%, SNF $8.312 \%$, TS $12.272 \%$, and milk density 1.029. Result showed that the lowest was by feed technology III, which was Rp. 1,143.80/l. Income Over Feed Cost (IOFC) showed that the use of feed technology III was more efficient than other feed technologies, which was Rp. 24,664.55/herd/day with the milk price of Rp. 4,207.55/l.
\end{abstract}

Key words: Feed technology, milk production, milk quality, milk price, feed price 


\section{PENDAHULUAN}

Usaha meningkatkan produksi dan kualitas susu dapat ditempuh melalui perbaikan manajemen pakan dan mutu genetik. Perbaikan melalui manajemen pakan lebih mudah dan cepat dilaksanakan oleh peternak, karena hanya dengan cara memilih bahan pakan dengan kualitas nutrisi dan karakteristik tertentu yang dapat meningkatkan produksi susu (Agus, 1997). Selain itu, pengaruh pakan terhadap produksi dan komposisi susu dapat diketahui dalam waktu yang relatif singkat jika dibandingkan melalui jalur pemuliaan ternak .

Kontribusi produksi susu terhadap ketersediaan susu nasional dihasilkan oleh peternakan sapi perah rakyat. Namun selama ini, susu yang merupakan produk utama dari usaha pemeliharaan sapi perah diproduksi menggunakan teknologi pakan yang masih standar. Teknologi pakan tersebut menyebabkan tidak terjadi peningkatan produksi susu mencapai produksi susu yang sesuai dengan potensi genetiknya. Alasan utama peternak belum dapat menerapkan teknologi pakan dikarenakan teknologi tersebut mahal sehingga tidak terjadi efisiensi penggunaan teknologi pakan yang berdampak pada penerimaan usaha pemeliharaan sapi perah yang rendah. Menurut Yusdjah (2005), Kontribusi biaya pakan (hijauan dan konsentrat) dalam produksi setiap liter susu mencapai $62,5 \%$. Hasil penelitian Mudikdjo et al. (2001), dibutuhkan $32,41 \%$ biaya konsentrat untuk memproduksi setiap liter susu. Tingginya biaya pakan ini akan berdampak pada pendapatan peternak.

Kondisi tingginya biaya pakan tidak selalu diikuti dengan meningkatnya harga susu. Harga pakan yang terus berflutuatif dan harga susu yang cenderung stagnan menyebabkan kondisi usaha sapi perah rakyat semakin terpuruk. Rendahnya marjin yang diterima oleh peternak dan tingginya biaya produksi terutama biaya pakan mengakibatkan peternak tidak mempunyai kemampuan untuk mengelola usahanya dengan optimal, sehingga jumlah dan kualitas susu yang dihasilkan rendah. Pada umumnya harga susu didasarkan pada produksi dan kualitas susu yang dihasilkan sehingga jika produksi dan kualiatas susu yang dihasilkan rendah maka berdampak pada rendahnya penerimaan.

Berdasarkan penelitian Priyanti dan Saptati (2008), elastisitas penawaran susu segar dan harga konsentrat di tingkat peternak cukup tinggi. Produksi susu sangat responsif terhadap variabel harga susu dan harga konsentrat. Parameter biaya pakan dan harga susu merupakan faktor utama dalam usaha pemeliharaan sapi perah. Teknologi pakan yang murah dan mampu meningkatkan produksi dan kualitas susu merupakan teknologi yang memiliki efisiensi penggunan yang tinggi oleh peternak sapi perah. Hal ini sesuai dengan pendapat Baba et al. (2011), jika peternak dapat menggunakan pakan berkualitas dengan harga yang lebih murah, maka usaha sapi perah dapat memberikan keuntungan yang lebih layak bagi usaha yang dilaksanakan. Oleh karena itu, diperlukan upaya penyediaan teknologi pakan yang dapat meningkatkan pendapatan peternak sapi perah.

Berdasarkan pemikiran di atas, maka penelitian ini bertujuan untuk mengkaji perubahan teknologi pakan terhadap perubahan parameter ekonomi (harga susu dan pakan) yang berdampak pada efisiensi penggunaan teknologi pakan oleh peternak sapi perah.

\section{MATERI DAN METODE}

Penelitian ini menggunakan data penelitian hasil percobaan tiga pakan alternatif yang diberikan pada 15 ekor ternak sapi perah Peranakan Friesian Holstein (PFH) laktasi awal (bulan 1-3) dengan produksi ratarata 13 liter/hari, umur ternak 3-4 tahun, dan 
berat badan ternak perah per ekor antara 400 $500 \mathrm{~kg}$ yang dilakukan pada kandang percobaan. Pemilihan ternak perah menggunakan metode Purposive Sampling. Pembatasan pada sampling dilakukan dengan membatasi pada keseragaman, umur ternak, masa laktasi, produksi susu, dan berat badan. Hasil produksi dan kualitas susu diukur sesuai dengan perkembangan harga susu tahun 2014.

Penggunaan teknologi pakan dibagi menjadi 3 yaitu teknologi pakan I, II, dan III. Teknologi pakan I merupakan pakan yang umumnya diberikan pada sapi perah yang terdiri dari rumput raja, ketela pohon, dan konsentrat komersil. Teknologi pakan II adalah bahan pakan pada teknologi pakan I yang ditambahkan (disuplementasi) dengan pakan High Quality Feed Supplement (HQFS). Teknologi pakan III adalah bahan pakan pada teknologi pakan I yang ditambahkan dengan Urea Molasses Multinutrients Block (UMMB). Perlakuan pakan terhadap ternak selama 42 hari dengan penggunaan pakan HQFS sebesar 300 g per produksi liter susu (Astuti et al., 2009) dan penggunaan UMMB sebanyak 300 g/ekor/hari. Pemberian pakan sapi perah dilakukan sebanyak 2 kali per hari yaitu pada pagi hari dan siang hari sehingga total kebutuhan pakan ternak setiap hari akan dibagi menjadi 2 bagian yang sama dan diberikan sesuai dengan jadwal pemberian pakan. Pakan HQFS merupakan pakan suplemen yang memiliki kualitas tinggi yang terdiri dari jagung giling, gaplek, konsentrat layer, mineral mix, tepung daun lamtoro, dan wheat bran. Komposisi UMMB terdiri dari Ampas kecap, bungkil kedelei, tetes, bekatul, tapioca, garam, urea, mineral, dan bungkil biji kapuk.

Data yang dikumpulkan berupa data produksi susu, kualitas susu berupa lemak, padatan tanpa lemak (Solid Non Fat), Total Solid (TS), berat jenis (BJ), dan harga susu serta harga pakan. Data perhitungan ekonomi dianalisis dengan menggunakan perhitungan
Income Over Feed Cost (IOFC) untuk mengetahui pendapatan yang diperoleh berdasarkan penjualaan susu dan pengeluaran biaya pakan.

\section{HASIL DAN PEMBAHASAN}

\section{Pemberian dan Konsumsi Pakan}

Teknologi pakan yang diberikan dalam penelitian terdiri dari teknologi pakan I, II, dan III. Teknologi pakan I terdiri dari hijauan, ketela pohon, konsentrat. Teknologi pakan II terdiri dari bahan pakan teknologi pakan I yang ditambahkan HQFS dan teknologi pakan III terdiri dari bahan pakan teknologi pakan I yang ditambahkan UMMB. Data rata-rata konsumsi bahan kering adalah jumlah dari konsumsi bahan kering hijauan, ketela pohon, konsentrat, UMMB, dan jerami fermentasi. Menurut Umiyasih dan Anggraeny (2008), kemampuan berproduksi susu pada sapi perah tidak hanya didasarkan atas volume yang dihasilkan, namun juga nilai gizi yang terkandung didalamnya sehingga pemberian pakan juga harus mempertimbangkan kualitas susu yang dihasilkan (Tabel 1).

Hasil menunjukkan bahwa total konsumsi pada sapi dengan teknologi pakan I, teknologi pakan II, dan teknologi pakan III masih dalam batas konsumsi bahan kering yang disarankan oleh NRC (1988) yaitu $2,25 \%$ sampai $4,32 \%$ dari berat badan. Menurut Siregar (1994) pemberian dan konsumsi hijauan dan konsentrat disesuaikan juga dengan status fisiologi, bobot dan produksi susu dari sapi tersebut. Konsumsi pakan pada kelompok teknologi pakan I, II, dan III telah sesuai dengan standar yang telah ditentukan sehingga kebutuhan energi ternak untuk kehidupan pokok dan produksi dapat terpenuhi. Ternak yang kekurangan energi dapat menurunkan aktivitas mikrobia dalam rumen sehingga dapat menurunkan konsumsi pakan (Mc Donald et al., 2002). 


\section{Produksi Susu}

Usaha sapi perah merupakan usaha yang sebagian besar pendapatan diperoleh dari produksi susu. Jumlah produksi susu setiap ternak sapi perah berbeda-beda tergantung pada faktor genetik dan lingkungan. Produksi susu sapi perah baik di peternak rakyat maupun di perusahaan berbeda bila dibandingkan produksi susu di negara asal sapi perah berada. Beberapa hasil penelitian menunjukkan bahwa sapi perah yang dipelihara di daerah tropis berproduksi 44\% lebih rendah jika dibandingkan pemeliharaan di daerah dingin. Prabowo (2008), menyatakan bahwa sapi perah daerah tropis dapat berproduksi sebanyak 2.353 liter/induk/tahun (Tabel 2).

Jenis pakan yang digunakan dalam usaha sapi perah akan menentukan jumlah produksi dan kualitas susu yang dihasilkan. Produksi yang dihasilkan dengan menggunakan pakan alternatif secara kuantitatif terdapat perbedaan. Penggunaan teknologi pakan III memiliki produksi tertinggi. Menurut sumber Badan Tenaga Nuklir Nasional (BATAN), pemberian UMMB pada sapi perah sebanyak 350-500 gram/ekor/hari dapat meningkatkan $14 \%$ produksi susu dalam satu masa laktasi.

\section{Kualitas Susu}

Pendapatan yang dihasilkan dari usaha sapi perah, selain tergantung dari produksi susu juga sangat tergantung dari kualitas susu. Kedua aspek ini sangat berperan penting dalam menentukan harga susu. Standar susu yang umumnya diterapkan menggunakan standar susu antara lain lemak, solid non fat (SNF), dan Total Solid (TS) (Tabel 3).

Penggunaan teknologi pakan yang berbeda pada kelompok percobaan secara kuantitatif menunjukkan bahwa kualitas susu dengan menggunakan teknologi pakan II memiliki kualitas yang lebih baik dari teknologi pakan yang lain. Kualitas susu yang dihasilkan dengan penggunaan teknologi pakan II secara keseluruhan telah memenuhi Standar Nasional Indonesia (SNI) maupun standar salah satu Industri Pengolahan Susu (IPS). Kualitas susu yang telah memenuhi syarat kualitas yang dipersyaratkan akan berdampak pada meningkatnya harga susu.

\section{Pendapatan Usaha Sapi Perah}

Usaha sapi perah tidak lepas dari pendapatan yang diperoleh. Pendapatan sapi perah sebagian besar diperoleh dari aktivitas penjualan susu. Aktivitas penjualan susu terkait dengan jumlah produksi dan kualitas susu yang dihasilkan sehingga diperlukan berbagai upaya untuk meningkatkan produksi dan kualitas susu. Perhitungan pendapatan usaha sapi perah berdasarkan pengeluaran biaya pakan sangat penting dilakukan mengingat pakan merupakan faktor produksi terbesar dalam usaha sapi perah sehingga peternak dapat mempertimbangkan teknologi pakan yang akan digunakan dalam meningkatkan kinerja keuangan usaha sapi perah. Aktivitas penjualan susu dalam usaha sapi perah meliputi penjualan susu berdasarkan kualitas susu yang meliputi Total Solid (TS) yang telah ditetapkan oleh koperasi. Penjualan susu sebagai aktivitas penggunaan teknologi pakan I menghasilkan harga susu per liter sebesar Rp. 4.010,47; teknologi pakan II menghasilkan sebesar Rp. 4.397,47; dan teknologi pakan III sebesar Rp. 4.207,55 (Tabel 4).

Hasil penelitian menunjukkan bahwa kualitas susu sangat menentukan harga susu per liter yang berdampak pada penerimaan susu secara total. Selain kualitas susu, jumlah produksi susu yang tinggi juga dapat memberikan penerimaan yang besar. Pendapat ini didukung oleh Setiadi (2006) bahwa penetapan harga berdasarkan kualitas susu akan memengaruhi harga jual susu yang diterima peternak. 
Tabel 1. Rata-rata konsumsi bahan kering (BK kg/ekor/hari)

\begin{tabular}{lccc}
\hline \hline \multicolumn{1}{c}{ Jenis Pakan } & $\begin{array}{c}\text { Teknologi Pakan I } \\
(\mathrm{kg})\end{array}$ & $\begin{array}{c}\text { Teknologi Pakan II } \\
(\mathrm{kg})\end{array}$ & $\begin{array}{c}\text { Teknologi Pakan III } \\
(\mathrm{kg})\end{array}$ \\
\hline Rumput raja & 0,74 & 0,74 & 0,74 \\
Ketela pohon & 0,35 & 0,35 & 0.35 \\
Konsentrat & 6,29 & 6,29 & 6.29 \\
HQFS & - & 1,72 & - \\
Jerami fermentasi & 4,98 & 4,68 & 5,62 \\
UMMB & - & - & 0,24 \\
\hline Total & 12,36 & 13,78 & 13,24 \\
\hline
\end{tabular}

Tabel 2. Rerata produksi susu pada penggunaan 3 teknologi pakan

\begin{tabular}{lcc}
\hline \multicolumn{1}{c}{ Jenis teknologi Pakan } & Produksi Susu per Ekor & $\begin{array}{c}\text { Rata-Rata Produksi Susu per Ekor } \\
\text { per Hari (1/ekor/hari) }\end{array}$ \\
\hline Teknologi pakan I & Selama 42 Hari (1/ekor) & 11,776 \\
Teknologi pakan II & 494,592 & 11,350 \\
Teknologi pakan III & 476,710 & 11,845 \\
\hline
\end{tabular}

Tabel 3. Rerata kualitas susu dan standar susu

\begin{tabular}{lrrrrr}
\hline \hline Kualitas susu & \multicolumn{3}{c}{ Teknologi Pakan } & \multirow{2}{*}{ Stándar SNI* } & Standar IPS** \\
\cline { 2 - 4 } & \multicolumn{1}{c}{ I } & \multicolumn{1}{c}{ II } & \multicolumn{1}{c}{ III } & & \\
\hline Lemak (\%) & 3,178 & 3,960 & 3,612 & Min. 3,00 & $3,00-4,50$ \\
Solid Non Fat (SNF) (\%) & 8,014 & 8,312 & 8,130 & 8,00 & $7,50-8,20$ \\
Total Solid (TS) (\%) & 11,192 & 12,272 & 11,742 & Min. 11,00 & $10,50-12,70$ \\
BJ & 1,029 & 1,029 & 1,028 & 1,028 & 1,027 \\
\hline
\end{tabular}

*SNI susu tahun 1998 dengan No. SNI 01-3141-1998 yang dikeluarkan oleh Badan Standar NasionalBSN.

** Standar Industri Pengolahan Susu (IPS) 2008.

Tabel 4. Penerimaan usaha sapi perah berdasarkan harga susu

\begin{tabular}{cccc}
\hline $\begin{array}{c}\text { Jenis Teknologi } \\
\text { Pakan }\end{array}$ & $\begin{array}{c}\text { Harga Susu per Liter } \\
\text { Berdasarkan \% TS } \\
\text { (Rp/liter) }\end{array}$ & $\begin{array}{c}\text { Rata - Rata Produksi } \\
\text { Susu per Ekor per } \\
\text { Hari (1/ekor/hari) }\end{array}$ & $\begin{array}{c}\text { Total Penerimaan } \\
\text { per Ekor per Hari } \\
\text { (Rp/ekor/hari) }\end{array}$ \\
\hline Teknologi pakan I & $4.010,47$ & 11,776 & $44.885,14$ \\
Teknologi pakan II & $4.397,47$ & 11,350 & $53.965,71$ \\
Teknologi pakan III & $4.207,55$ & 11,845 & $49.405,05$ \\
\hline
\end{tabular}

Berkaitan dengan proses produksi susu, maka faktor yang berperan dalam proses tersebut adalah faktor pakan. Menurut
Hertanto (2012), bahwa biaya pakan yang dikeluarkan oleh peternak sapi perah untuk memelihara satu ekor sapi laktasi per tahun 
sebesar 71,39\%. Persentasi biaya pakan terhadap biaya produksi yang sangat tinggi, Tabel 5. Biaya pakan untuk memproduksi susu

\begin{tabular}{lcc}
\hline \hline Jenis Teknologi Pakan & $\begin{array}{c}\text { Biaya Pakan per Ekor per Hari } \\
\text { (Rp/ekor/hari) }\end{array}$ & $\begin{array}{c}\text { Biaya Pakan per Liter Susu } \\
(\mathrm{Rp} / \mathrm{l})\end{array}$ \\
\hline Teknologi pakan I & $23.602,00$ & $1.167,26$ \\
Teknologi pakan II & $29.420,00$ & $1.355,76$ \\
Teknologi pakan III & $24.740,50$ & $1.143,80$ \\
\hline
\end{tabular}

Tabel 6. Nilai Income Over Feed Cost (IOFC) penggunaan teknologi pakan sapi perah per ekor per hari

\begin{tabular}{lc}
\hline \hline \multicolumn{1}{c}{ Jenis Teknologi Pakan } & Nilai IOFC (Rp)* \\
\hline Teknologi pakan I & $21.283,14$ \\
Teknologi pakan II & $24.545,71$ \\
Teknologi pakan III & $24.664,55$ \\
\hline
\end{tabular}

*Nilai IOFC = Rata-rata penerimaan susu per ekor per hari (Rp) - Rata-rata biaya pakan per ekor per hari (Rp).

maka diperlukan perhitungan biaya pakan yang dikeluarkan untuk menghasilkan setiap liter susu (Tabel 5).

Berdasarkan hasil perhitungan biaya pakan per liter susu diperoleh biaya pakan terkecil atau termurah adalah penggunaan teknologi pakan III sebesar Rp. 1.143,80/liter. Hasil ini jauh lebih murah bila dibandingkan dengan penelitian Nurtini dan Suranindyah (2008) di perusahan sapi perah yang mencapai Rp. 1.573,33/liter susu. Penggunaan biaya pakan sapi perah yang besar dapat berdampak pada berkurangnya pendapatan sapi perah. Namun, penggunaan biaya pakan yang besar dapat diterima penggunaannya jika pakan yang digunakan dapat meningkatan produksi dan kualitas susu yang dihasilkan sehingga dapat meningkatkan pendapatan. Berkaitan dengan jenis teknologi pakan yang dapat meningkatkan pendapatan peternak, maka perlu dilakukan perhitungan pendapatan yang didasarkan pada biaya pakan dengan menggunakan analisis Income Over Feed Cost (IOFC) (Tabel 6).

Hasil perhitungan IOFC menunjukkan penggunaan teknologi pakan III memiliki nilai IOFC yang paling tinggi sebesar Rp. 24.664,55/ekor/hari. Hal ini disebabkan biaya yang dikeluarkan untuk menghasil 1 liter susu lebih rendah dibandingkan teknologi pakan yang lain. Selain itu, teknologi pakan III menghasilkan jumlah produksi susu tertinggi dan harga susu yang diperoleh tidak begitu jauh dengan teknologi pakan II yang memiliki kualitas susu yang paling baik. Hasil penilitian ini jauh lebih baik dibandingkan penelitian Nurtini dan Suranindyah (2008) yang menunjukkan nilai IOFC per ekor sapi laktasi sebesar Rp. 18.200,00 dengan harga susu per liter sebesar Rp. 4.000,00 dan ratarata produksi susu per ekor sebesar 7,5 liter.

Berdasarkan parameter ekonomi yaitu harga susu dan biaya pakan, maka teknologi pakan III memiliki efisensi yang tinggi dibandingkan teknologi pakan yang lain. Hal ini dikarenakan teknologi pakan III mampu memberikan pendapatan yang lebih tinggi.

\section{SIMPULAN}

Berdasarkan hasil perhitungan
ekonomi dengan mempertimbangkan
parameter harga pakan dan harga susu bahwa
penggunaan teknologi pakan III (suplementasi
UMMB) memiliki efisiensi yang lebih baik
dibandingkan teknologi pakan lain dengan
nilai Income Over Feed Cost (IOFC) sebesar
Rp. 24.664,55/ekor/hari dengan harga susu


sebesar Rp. 4.207,55/liter dan biaya pakan per liter susu sebesar Rp. 1.143,80.

\section{DAFTAR PUSTAKA}

Agus, A. 1997. Pengaruh Tipe Konsentrat Sumber Energi dalam Ransum Sapi Perah Berproduksi Tinggi Terhadap Produksi dan Komposisi Susu. Buletin Peternakan 21(1): 37-44.

Astuti, A, A. Agus, dan S. P.S. Budhi. 2009. Pengaruh Penggunaan High Quality Feed Supplement Terhadap Konsumsi Dan Kecernaan Nutrien Sapi Perah Awal Laktasi. Buletin Peternakan 33(2): 81-87.

Babaa, S, A. Muktianib, A. Akoa, dan M. I. A. Dagonga. 2011. Keragaman dan kebutuhan teknologi pakan peternak sapi perah di Kabupaten Enrekang. Media Peternakan. 34(2): 146-154.

Hertanto, B.S. 2012. Analisis ekonomi Usaha Sapi Perah serta Strategi Pengembangannya pada Peternakan Rakyat dan Perusahaan di Dataran Rendah. Tesis. Program Pascasarjana. Fakultas Peternakan. Universitas Gadjah Mada. Yogyakarta.

McDonald, P., R. A. Edwards and J. F. D. Greenhalg. 2002. Animal Nutrition, $6^{\text {th }}$ ed. English Language Book Society. Longman London.

Mudikdjo, K., U. Sehabuddin, dan R. Pambudi. 2001. Analisis ekonomi usaha sapi perah di wilayah Propinsi Jawa Barat. Media Peternakan. Edisi Khusus 24: 57-66.

NRC. 1988. Nutrient Requierement Of Dairy Cattle. $6^{\text {th }}$ Edition. The Morrison Publishing Co. Cleremont.
Nurtini dan Y.Y. Suranindyah. 2008. Penampilan usaha sapi perah dengan menggunakan pakan jerami fermentasi. Dalam: Prosiding Semiloka Nasional Prospek Industri Sapi Perah Menuju Perdagangan Bebas- 2020. hal: 420-424.

Prabowo, H. S. 2008. Dairy farming in Pakistan. Bulletin Perhimpunan Dokter Hewan Indonesia Cabang Jawa Timur II. Edisi X.

Priyanti, A. dan R. A. Saptati. 2008. Dampak harga susu terhadap harga susu dalam negeri tingkat peternak: kasus koperasi peternak sapi bandung utara di jawa barat. Dalam: Prosiding Seminar Nasional Dinamika Pembangunan Pertanian dan Pedesaan: Tantangan dan Peluang bagi Peningkatan Kesejahteraan Petani. Bogor, 19 November 2008. hal: 1-10.

Setiadi, D. 2006. Peningkatan kualitas manajemen sapi perah di koperasi. Makalah disampaikan pada Lokakarya Sapi Perah Nasional. Balai Penelitian Ternak. Bogor, 23 November 2006.

Siregar, S. 1994. Sapi Perah Jenis, Teknik Pemeliharaan dan Analisis Usaha. PT. Penebar Swadaya. Jakarta.

Umiyasih, U. dan Y. N. Anggraeny. 2008. Strategi pakan alternatif sebagai upaya efisiensi pada usaha sapi perah rakyat. Dalam: Prosiding Semiloka Nasional Prospek Industri Sapi Perah Menuju Perdagangan Bebas - 2020. hal: 226-231.

Yusdja, Y. 2005. Kebijakan ekonomi industri agribisnis sapi perah di Indoonesia. Analisis Kebijakan Pertanian. 3(3): 257-268. 